\title{
Effect of Genotype, Planting Date, and Spacing on Zoysiagrass Establishment from Vegetative Plugs
}

\author{
Bradley S. Sladek, Gerald M. Henry ${ }^{1}$, and Dick L. Auld \\ Department of Plant and Soil Science, Texas Tech University, Box 42122, \\ Lubbock, TX 79409
}

Additional index words. Zoysia japonica, Zoysia matrella, growth rate, plant density

\begin{abstract}
Slow growth and establishment rate has become a major limitation to the increased use of zoysiagrass (Zoysia spp.) as a turfgrass surface. Two separate field studies were conducted to evaluate the effect of genotype, planting date, and plug spacing on zoysiagrass establishment. Field experiments were conducted in 2007 and 2008 to quantify the establishment rate of six zoysiagrass genotypes from vegetative plugs. 'Meyer' exhibited the largest plug diameter $(22 \mathrm{~cm}) 6$ weeks after planting (WAP). In contrast, 'Diamond' exhibited the smallest plug diameter $(13 \mathrm{~cm}) 6$ WAP. A similar trend was observed 12 WAP. 'Meyer', 'Zorro', and 'Shadow Turf' exhibited the largest plug diameters $(60,58$, and $57 \mathrm{~cm}$, respectively) 12 WAP. In contrast, 'Emerald' and 'Diamond' exhibited the smallest plug diameters $(41$ and $40 \mathrm{~cm}$, respectively) 12 WAP. Although statistically different, all zoysiagrass genotypes reached similar establishment 18 WAP indicating that plugging these genotypes in a comparable environment and using techniques described in this research may result in analogous long-term (18 weeks) establishment. Field experiments were conducted in 2006 and 2007 to determine the optimum planting date and plug spacing of 'Shadow Turf' zoysiagrass. 'Shadow Turf' zoysiagrass plugs planted on 28 July 2006 (11\% to 65\% cover) and 14 June 2007 (5\% to $39 \%$ cover) exhibited the greatest increase in turfgrass cover 6 WAP, except for plugs planted $15.2 \mathrm{~cm}$ apart on 26 May 2006 (74\% cover). Zoysiagrass cover was greatest for plugs planted on 26 May $2006(63 \%$ to $100 \%)$ and 17 May 2007 (46\% to $97 \%) 16$ WAP regardless of plug spacing. These planting dates corresponded to the highest accumulative growing degree-days (GDD) experienced by all planting dates in both years. Plugs planted on 15.2-cm centers exhibited the greatest zoysiagrass cover 6 and 16 WAP regardless of planting date. Using late spring/early summer planting dates and $15.2-$ to $30.5-\mathrm{cm}$ plug spacings may result in the quickest turfgrass cover when establishing 'Shadow Turf' zoysiagrass from plugs.
\end{abstract}

Zoysiagrass (Zoysia spp.) is a warm-season, perennial turfgrass native to parts of China, Japan, and Korea (Engelke and Anderson, 2003). It is adapted throughout the southern region of the United States to the northern transition zone. Zoysiagrass forms a dense, uniform turf through the production and spread of rhizomes and stolons (Turgeon, 2008). It is predominantly used on golf courses, athletic fields, home lawns, and commercial landscapes. Adaptation to a wide range of environmental conditions has further led to an increase in zoysiagrass popularity. Zoysiagrass tolerates reduced light intensity (Barrios et al.,

\footnotetext{
Received for publication 21 July 2009. Accepted for publication 11 Mar. 2011.

Texas Tech University manuscript no. T-4-604. We acknowledge the cooperation of Justin Weeaks, Dr. Michael Maurer, Steve Oswalt, Nick Sanford, and Aaron Holbrook for their technical assistance on this project. Appreciation is also extended to Mark Ivey for providing 'Shadow Turf' and 'Meyer' zoysiagrass gsermplasm. Additional thanks are extended to Dr. Milt Engelke for providing DALZ 0501, 'Diamond', 'Zorro', and 'Emerald' zoysiagrass germplasm.

${ }^{1}$ To whom reprint requests should be addressed; e-mail gerald.henry@ttu.edu.
}

1986; Morton et al., 1991; Qian and Engelke, 1999a), moderate salinity (Marcum et al., 1998; Qian et al., 2000), moderate drought conditions (Qian and Engelke, 1999b; White et al., 2001), and exposure to low temperatures (Patton and Reicher, 2007; Patton et al., 2007a, 2007b; Warmund et al., 1998). However, slow growth and establishment rate has become a major limitation to the increased use of zoysiagrass. Zoysiagrass establishment by plugs or sprigs can take up to 2 years, or longer, to reach complete coverage (Hume and Freyre, 1950; Sifers et al., 1992a, 1992b). Delayed establishment may increase plant desiccation (Richardson and Boyd, 2001), weed encroachment (Harivandi et al., 1995), and maintenance costs during establishment (Henry et al., 1988).

Zoysiagrass species and cultivar selection may impact establishment rate and turfgrass cover after one growing season (Forbes and Ferguson, 1947; Henry et al., 1988; Patton et al., 2007c; Sifers et al., 1992a, 1992b). Faster establishment rates have been observed for $Z$. japonica cultivars than for $Z$. matrella cultivars (Forbes and Ferguson, 1947; Patton et al., 2007c). Planting date may also impact zoysiagrass establishment rate. Patton et al. (2004) reported optimum establishment time of zoysiagrass from seed was from 1 to 15 June. Establishment of 'El Toro' zoysiagrass planted from sprigs and plugs during early summer took 3 to 4 months to establish, whereas those planted in fall and spring took 9 and 11 months, respectively (Henry et al., 1988). Planting zoysiagrass plugs during early summer may optimize exposure to warm temperatures favorable for growth and establishment. Beard (1973) suggested spacing zoysiagrass plugs between 15.2 and $40.6 \mathrm{~cm}$ on center; however, minimal research has been conducted to determine the optimum zoysiagrass plug spacing to achieve adequate turf cover ( $85 \%$ or greater) at the end of a single growing season.

The measurement of accumulated GDD has been used to monitor growth and phonological stages in apricot (Prunus armeniaca L.) and peach (P. persica L.) (Valentini et al., 2004), sour cherry (P. cerasus L.) (Zavalloni et al., 2006), annual bluegrass (Poa annua L.) (Danneberger and Vargas, 1984) as well as many warm-season grasses (Madakadze et al., 1998). Modeling the relationship of plant growth to temperature may be achieved by calculating GDD. The model is applied by subtracting a base temperature from the daily mean air temperature to obtain a GDD value for each day. Daily GDD values are summed to obtain the relative number of GDD that have accumulated over a given time period. Previous research determined the use of a $5{ }^{\circ} \mathrm{C}$ base temperature for calculating the accumulation of GDD for Zoysia spp. (Patton et al., 2004; Unruh et al., 1996). The use of accumulated GDD may increase the understanding of the relationship between zoysiagrass growth and planting date.

Selecting zoysiagrass genotypes with improved establishment rates may reduce the time required to reach adequate ( $85 \%$ or greater) turfgrass cover. Use of late spring to early summer planting dates and determination of optimum plug spacing may enhance zoysiagrass establishment and reduce maintenance costs. Therefore, the objectives of our research were to quantify the establishment rate of six zoysiagrass genotypes established from plugs and determine the optimum planting date and plug spacing of 'Shadow Turf' zoysiagrass to achieve adequate turf cover (greater than $85 \%$ ).

\section{Materials and Methods}

Rate of spread trial. Experiments were conducted in 2007 and 2008 at the Texas Tech Turfgrass Research Station in Lubbock, TX, on a Brownfield sandy clay loam (loamy, mixed, superactive, thermic Arenic Aridic Paleustalfs) with a $\mathrm{pH}$ of 8.2. Plugs measuring $10 \mathrm{~cm}$ in diameter of six zoysiagrass genotypes [Z. japonica genotype ('Meyer'); $Z$. matrella genotypes ('Shadow Turf', 'Diamond', 'DALZ 0501', and 'Zorro'); Z. japonica $\times Z$. pacifica genotype ('Emerald')] were vegetatively propagated in the greenhouse by planting three stolons with three nodes each in potting medium containing 55\% bark, $20 \%$ Canadian sphagnum peatmoss, $10 \%$ perlite, $15 \%$ vermiculite, dolomitic lime, gypsum, and 
a wetting agent (Sun Gro Horticulture, Vancouver, British Columbia, Canada). Zoysiagrass genotypes were selected to represent a wide variety of growth rates and habits ('DALZ 0501', 'Diamond', 'Zorro', and 'Emerald' were provided by Dr. Milt Engelke; 'Shadow Turf' and 'Meyer' were provided by Mark Ivey). Plugs were irrigated frequently to encourage rooting of zoysiagrass stolons and then as needed to prevent wilting and encourage growth. Plugs were fertilized $(21 \mathrm{~N}-3.5 \mathrm{P}-$ 14.9K) (The Scotts Company, Marysville, $\mathrm{OH})$ every 2 weeks at a rate of $24.4 \mathrm{~kg} \cdot \mathrm{ha}^{-1}$ nitrogen $(\mathrm{N})$ to encourage establishment. Plugs were grown in the greenhouse for $\approx 8$ weeks until reaching $100 \%$ cover. The research area was cultivated in two directions with a tractor-mounted rototiller to a depth of $10.2 \mathrm{~cm}$ before plug transplant. Nine plugs (10 $\mathrm{cm}$ in diameter) of each genotype were transplanted $30.5 \mathrm{~cm}$ apart in $1 \mathrm{~m} \times 1-\mathrm{m}$ plots on 15 May 2007 and 5 May 2008. Plots were arranged in a randomized complete block design with four replications of genotypes. Fertilizer (16N-10.5P-9.9K) (The Andersons, Inc., Maumee, $\mathrm{OH}$ ) was applied at the time of transplant at a rate of $24.4 \mathrm{~kg} \cdot \mathrm{ha}^{-1} \mathrm{~N}$. Monthly applications of fertilizer (16N-10.5P-9.9K) (The Andersons, Inc.) were made throughout the duration of the study at a rate of 24.4 $\mathrm{kg} \cdot \mathrm{ha}^{-1} \mathrm{~N}$. Plants were mowed twice weekly and maintained at a height of $1.9 \mathrm{~cm}$ with a walk-behind reel mower (Toro Greensmaster 1600; The Toro Company, Bloomington, MN). Irrigation was applied as a supplement to rainfall at a rate of 2.5 to $3.0 \mathrm{~cm} /$ week. Plots were maintained weed free by hand-weeding and through spot applications of glyphosate $\left(0.28 \mathrm{~kg} \cdot \mathrm{ha}^{-1}\right)$ with a handheld pump sprayer (Solo, Newport News, VA) to reduce the effects of weed competition.

Lateral plant diameters were recorded at the beginning of each study and every 2 weeks thereafter for a total of 4 months. Two diameter measurements were taken perpendicular to each other (the first measurement was taken in the largest diameter) and averaged to obtain the reported diameter of each plant at each sampling time. Maximum plug diameter $(61 \mathrm{~cm})$ was obtained when plugs grew to the center of an adjacent plug. Data from three plugs (lower left, middle center, and upper right) were averaged to give estimates for each plot.

Data were subjected to analysis of variance (ANOVA) using the PROC GLM procedure provided by SAS (SAS 9.2 software; SAS Institute Inc., Cary, NC) and means were separated using Fisher's protected least significant difference (LSD) test at the $0.05 P$ level. Data were pooled across years to test for significant year interactions. The arcsine square root transformations of plant diameter and percent zoysiagrass cover data were also subject to ANOVA but were not different from non-transformed data; therefore, nontransformed data are presented.

Plug spacing and planting date trial. Experiments were conducted in 2006 and 2007 at the Texas Tech Turfgrass Research Station in Lubbock, TX, on a Brownfield sandy clay loam (loamy, mixed, superactive, thermic Arenic Aridic Paleustalfs). Plugs measuring $2.5 \mathrm{~cm}$ in diameter of the $Z$. matrella genotype 'Shadow Turf' were vegetatively propagated in the greenhouse in potting medium containing 55\% bark, 20\% Canadian sphagnum peatmoss, $10 \%$ perlite, $15 \%$ vermiculite, dolomitic lime, gypsum, and a wetting agent (Sun Gro Horticulture). Plugs were propagated and maintained using the same techniques described in the previous trial. A $3 \times 6$ factorial arranged in a split-plot design with four replications was used to evaluate planting date (main plot) and plug spacing (subplot within planting date). The six plug spacings were 15.2, 22.9, 30.5, 38.1, 45.7, and $61.0 \mathrm{~cm}$. Experimental plots were cultivated in two directions with a tractor-mounted rototiller to a depth of $10.2 \mathrm{~cm}$ before plug transplant. Plugs were transplanted into $1 \mathrm{~m} \times 1-\mathrm{m}$ plots on 26 May 2006 and 17 May 2007; 20 June 2006 and 14 June 2007; and 28 July 2006 and 13 July 2007. Fertilizer (16N-10.5P-9.9K) (The Andersons, Inc.) was applied at time of transplant at a rate of $24.4 \mathrm{~kg} \cdot \mathrm{ha}^{-1} \mathrm{~N}$. Fertilizer $(16 \mathrm{~N}-10.5 \mathrm{P}-9.9 \mathrm{~K})$ (The Andersons, Inc.) applications were made every 2 weeks throughout the duration of the study at a rate of 24.4 $\mathrm{kg} \cdot \mathrm{ha}^{-1} \mathrm{~N}$. Plants were mowed twice weekly and maintained at a height of $1.9 \mathrm{~cm}$ with a walk-behind reel mower (Toro Greensmaster 1600; The Toro Company). Irrigation was applied as a supplement to rainfall at a rate of 2.5 to $3.0 \mathrm{~cm} /$ week. Plots were maintained weed free by hand-weeding and through spot applications of glyphosate $\left(0.28 \mathrm{~kg} \cdot \mathrm{ha}^{-1}\right)$ with a handheld pump sprayer (Solo) to reduce the effects of weed competition.

Percent zoysiagrass cover was visually estimated for each plot every 2 weeks for the duration of the experiment on a scale of $0 \%$ (no cover) to $100 \%$ (complete turfgrass cover). Although turfgrass cover was further quantified using digital image analysis, visual ratings are presented. Maximum turfgrass cover was obtained when plug cover approached $100 \%$ (12 and 14 WAP).

GDD values were calculated by subtracting the base growth temperature of zoysiagrass $\left(5^{\circ} \mathrm{C}\right)$ from the daily mean air temperature. Daily GDDs were summed to obtain a GDD value for the 6 and $16 \mathrm{WAP}$ time periods for each respective planting date. Mean air temperature was based on weather data collected from a weather station located at the Texas Tech Turfgrass Research Station. The weather station was located in an irrigated tall fescue (Festuca arundinacea Schreb.) research field maintained at a height of $7.6 \mathrm{~cm}$.

Data were subjected to ANOVA using error partitioning appropriate to a split-plot analysis in the general linear models procedure (PROC GLM) provided by SAS. Data were pooled across years to test for significant year interactions. The arcsine square root transformations of percent zoysiagrass cover data were also subjected to ANOVA but were not different from non-transformed data; therefore, non-transformed data are presented. Means were separated using Fisher's protected LSD test at the $0.05 P$ level.

\section{Results}

Rate of spread trial. Analysis of variance revealed an insignificant genotype-by-year interaction $(P=0.4896)$; therefore, data for 2007 and 2008 were pooled and are presented together. A significant genotype effect $(P<$ 0.0001 ) was observed for all data.

Zoysiagrass establishment was slow (36\% cover or less) regardless of genotype at 6 WAP. Meyer exhibited the largest plug diameter 6 WAP $(22 \mathrm{~cm})$ (Table 1). Plug diameters of the remaining zoysiagrass genotypes ranged from 13 to $19 \mathrm{~cm} 6$ WAP with 'Diamond' $(13 \mathrm{~cm})$ exhibiting the least amount of growth.

A similar trend in zoysiagrass growth and establishment was observed 12 WAP. 'Meyer' continued to exhibit the largest plug diameter 12 WAP $(60 \mathrm{~cm})$ (Table 1). Significant statistical and biological differences were observed among the remaining zoysiagrass genotypes. 'Zorro' and 'Shadow Turf' exhibited excellent growth (94\% cover) 12 WAP (58 and $57 \mathrm{~cm}$, respectively), whereas 'DALZ 0501' displayed moderate growth $(85 \%$ cover $) 12$ WAP $(51 \mathrm{~cm})$. 'Emerald' and 'Diamond' exhibited the least amount of growth 12 WAP with plug diameters of 41 and $40 \mathrm{~cm}$, respectively (Table 1).

Although significant statistical differences in zoysiagrass growth and establishment were observed 18 WAP, biological differences were minimal. All zoysiagrass genotypes exhibited similar plug diameters (53 to $60 \mathrm{~cm}$ ), which correlated to similar turfgrass coverage ( $87 \%$ or greater) $18 \mathrm{WAP}$ (Table 1).

Plug spacing and planting date trial. Analysis of variance revealed a significant planting date-by-year $(P<0.0001)$ interaction; therefore, data for 2006 and 2007 are presented separately. Significant main plot effects of planting date $(P<0.0001)$ and subplot effects of plug spacing $(P<0.0001)$ were observed for all data in 2006 and 2007. A significant planting date-by-plug spacing $(P<0.0001)$ interaction was also observed in both years.

Table 1. Mean plug diameter $(\mathrm{cm})$ of 6 zoysiagrass genotypes evaluated for rate of spread 6,12 , and $18 \mathrm{WAP}^{\mathrm{z}}$ in 2007 and 2008 at Lubbock, TX.

\begin{tabular}{lccc}
\hline & \multicolumn{3}{c}{ Plug diam $^{y}$} \\
\cline { 2 - 4 } Genotype $^{\mathrm{x}}$ & 6 WAP & $12 \mathrm{WAP}$ & $18 \mathrm{WAP}$ \\
\cline { 2 - 4 }$-----------\mathrm{cm}$ & $22 \mathrm{a}^{\mathrm{w}}$ & $60 \mathrm{a}$ & $60 \mathrm{a}$ \\
\hline Meyer & $19 \mathrm{~b}$ & $57 \mathrm{~b}$ & $59 \mathrm{a}$ \\
Shadow Turf & $18 \mathrm{~b}$ & $58 \mathrm{ab}$ & $59 \mathrm{a}$ \\
Zorro & $18 \mathrm{~b}$ & $51 \mathrm{c}$ & $57 \mathrm{~b}$ \\
DALZ 0501 & $16 \mathrm{c}$ & $41 \mathrm{~d}$ & $54 \mathrm{c}$ \\
Emerald & $13 \mathrm{~d}$ & $40 \mathrm{~d}$ & $53 \mathrm{c}$ \\
Diamond &
\end{tabular}

${ }^{\mathrm{z}} \mathrm{WAP}=$ weeks after planting.

${ }^{\mathrm{y}}$ Maximum plug diameter was achieved when plugs measured $61 \mathrm{~cm}$.

${ }^{\mathrm{x}}$ Z. japonica genotype (Meyer); Z. matrella genotypes (Shadow Turf, Zorro, DALZ 0501, and Diamond); $Z$. japonica $\times Z$. pacifica genotype (Emerald).

${ }^{\text {w}}$ Means within a column followed by the same lower case letter are not significantly different at $P \leq 0.05$ according to Fisher's protected least significant difference test. 
Percent zoysiagrass cover exhibited a linear response to plug spacing 6 WAP. The closer the plug spacing, the greater the zoysiagrass cover regardless of planting date and year. In 2006, zoysiagrass plugs spaced $15.2 \mathrm{~cm}$ apart and planted on 26 May exhibited the largest growth (74\% cover) 6 WAP followed by 28 July ( $65 \%$ cover) and 20 June $(58 \%$ cover) (Table 2). Plugs planted on 28 July exhibited the largest growth (11\% to $46 \%$ cover) $6 \mathrm{WAP}$ for the remainder of the plug spacings. In 2007, zoysiagrass plugs spaced $15.2 \mathrm{~cm}$ apart and planted on 14 June exhibited the largest growth (39\% cover) 6 WAP followed by 17 May (38\% cover) and 13 July (35\% cover) (Table 2). Plugs planted on 14 June exhibited the largest growth (15\% to $23 \%$ cover) 6 WAP for the remainder of the plug spacings.

Percent zoysiagrass cover exhibited a linear response to plug spacing $16 \mathrm{WAP}$. The closer the plug spacing, the greater the zoysiayear. Zoysiagrass plugs spaced $15.2 \mathrm{~cm}$ apart exhibited $84 \%$ to $100 \%$ cover 16 WAP regardless of planting date and year. Plugs spaced $15.2 \mathrm{~cm}$ apart and planted on 26 May 2006 and 20 June 2006 reached $100 \%$ cover 12 and 14 WAP, respectively. In 2006, percent zoysiagrass cover was greatest for plugs planted on 26 grass cover regardless of planting date and

May ( $63 \%$ to $100 \%$ ) followed by 20 June $(55 \%$ to $100 \%$ ) and 28 July ( $20 \%$ to $84 \%$ ) regardless of plug spacing (Table 3). In 2007, percent zoysiagrass cover was greatest for plugs planted on 14 June ( $54 \%$ to $95 \%$ ), except for plugs spaced $15.2 \mathrm{~cm}$ apart, which exhibited the greatest percent zoysiagrass cover when planted on 17 May (97\%) (Table 3).

Differences in zoysiagrass establishment from year to year may be explained by examining accumulated GDD. 'Shadow Turf' zoysiagrass plugs were exposed to greater accumulative GDD in 2006 compared with 20076 WAP. In 2006, plugs planted on 26 May, 20 June, and 28 July were exposed to 919,940 , and 848 accumulative GDDs, respectively (Table 4). In contrast, plugs planted on 17 May 2007, 14 June 2007, and 13 July 2007 were exposed to 726, 834, and 890 accumulative GDDs, respectively (Table 4). Conversely, plugs planted in 2007 were exposed to greater GDDs than those planted in 200616 WAP with the exception of those planted in May. In 2006, plugs planted on 26 May, 20 June, and 28 July were exposed to 2358, 2171, and 1638 accumulative GDDs, respectively (Table 4). In contrast, in 2007, zoysiagrass plugs planted on 17 May, 14 June, and 13 July were exposed to 2146, 2213, and 1989 GDDs, respectively (Table 4).

Table 2. Mean 'Shadow Turf' zoysiagrass cover (\%) $6 \mathrm{WAP}^{\mathrm{z}}$ as affected by planting date and plug spacing in 2006 and 2007 at Lubbock, TX.

\begin{tabular}{|c|c|c|c|c|c|c|}
\hline \multirow{5}{*}{$\begin{array}{l}\text { Plug } \\
\text { spacing }(\mathrm{cm})\end{array}$} & \multicolumn{6}{|c|}{ Zoysiagrass cover } \\
\hline & \multicolumn{3}{|c|}{$6 \mathrm{WAP}$} & \multicolumn{3}{|c|}{$6 \mathrm{WAP}$} \\
\hline & \multicolumn{3}{|c|}{2006 Planting Dates } & \multicolumn{3}{|c|}{2007 Planting Dates } \\
\hline & 26 May & 20 June & 28 July & 17 May & 14 June & 13 July \\
\hline & \multicolumn{6}{|c|}{ 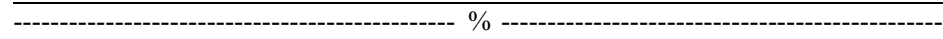 } \\
\hline$\frac{1}{15.2}$ & $74 \mathrm{aA}^{\mathrm{y}}$ & $58 \mathrm{cA}$ & $65 \mathrm{bA}$ & 38 abA & $39 \mathrm{aA}$ & $35 \mathrm{bA}$ \\
\hline 22.9 & $43 \mathrm{~dB}$ & $35 \mathrm{eB}$ & $46 \mathrm{~dB}$ & $20 \mathrm{cB}$ & $23 \mathrm{cB}$ & $15 \mathrm{~dB}$ \\
\hline 30.5 & $28 \mathrm{fC}$ & $25 \mathrm{fgC}$ & $33 \mathrm{eC}$ & $11 \mathrm{eC}$ & $15 \mathrm{dC}$ & $10 \mathrm{eC}$ \\
\hline 38.1 & $23 \mathrm{ghC}$ & $20 \mathrm{hC}$ & $25 \mathrm{fgD}$ & $9 \mathrm{eCD}$ & $15 \mathrm{dC}$ & $10 \mathrm{eC}$ \\
\hline 45.7 & $10 \mathrm{jD}$ & $11 \mathrm{ijD}$ & $15 \mathrm{iE}$ & $5 \mathrm{fD}$ & $5 \mathrm{fD}$ & $5 \mathrm{fD}$ \\
\hline 61.0 & $11 \mathrm{ijD}$ & $10 \mathrm{jD}$ & $11 \mathrm{ijE}$ & $5 \mathrm{fD}$ & $5 \mathrm{fD}$ & $5 \mathrm{fD}$ \\
\hline
\end{tabular}

${ }^{2} \mathrm{WAP}=$ weeks after planting.

${ }^{\mathrm{y}}$ Means within columns of a specific planting year followed by the same lowercase letter are not significantly different at $P \leq 0.05$ according to Fisher's protected least significant difference (LSD) test. Means within a column followed by the same uppercase letter are not significantly different at $P \leq 0.05$ according to Fisher's protected LSD test.

Table 3. Mean 'Shadow Turf' zoysiagrass cover (\%) $16 \mathrm{WAP}$ as affected by planting date and plug spacing in 2006 and 2007 at Lubbock, TX.

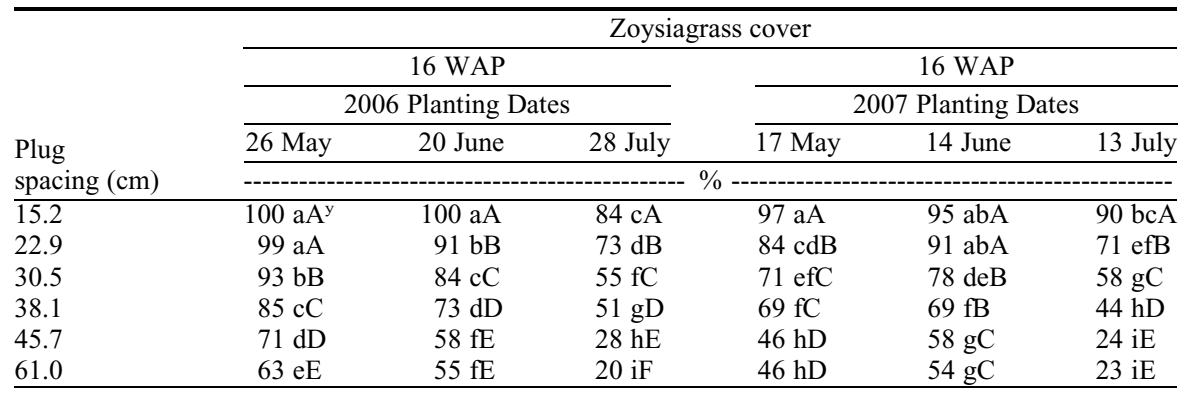

${ }^{\mathrm{z}} \mathrm{WAP}=$ weeks after planting.

${ }^{y}$ Means within columns of a specific planting year followed by the same lowercase letter are not significantly different at $P \leq 0.05$ according to Fisher's protected least significant difference (LSD) test. Means within a column followed by the same uppercase letter are not significantly different at $P \leq 0.05$ according to Fisher's protected LSD test.

\section{Discussion}

Typically, Z. japonica genotypes exhibit quicker establishment rates than $Z$. matrella genotypes (Forbes and Ferguson, 1947). Henry et al. (1988) reported $90 \%$ turfgrass cover of the $Z$. japonica cultivar El Toro 12 WAP, whereas a $Z$. matrella genotype required 8 months to reach similar coverage. In this research, the $Z$. japonica genotype 'Meyer' exhibited the largest increase in plug diameter $(60 \mathrm{~cm})$ regardless of evaluation date. Patton et al. (2007c) observed greater coverage (2151 to $4142 \mathrm{~cm}^{2}$ ) $91 \mathrm{~d}$ after planting (DAP) with 13 $Z$. japonica genotypes. However, the $Z$. japonica genotype Meyer exhibited significantly less coverage $\left(1203 \mathrm{~cm}^{2}\right) 91$ DAP (Patton et al., 2007c). Turfgrass cover for $Z$. matrella genotypes ranged from 425 ('Diamond') to 1931 ('Zorro') $\mathrm{cm}^{2} 91$ DAP (Patton et al., 2007c). Growth of 'Zorro' in this research was observed to be statistically similar to Meyer 12 and 18 WAP. The $Z$. japonica $\times Z$. pacifica genotype 'Emerald' and the $Z$. matrella genotype 'Diamond' exhibited the smallest increase in plug diameter with diameters ranging from 13 to $16 \mathrm{~cm} 12$ WAP and 40 to $41 \mathrm{~cm} 18$ WAP. Slow establishment rates of 'Emerald' and 'Diamond' were also noted by Patton et al. (2007c). Minimal research has been conducted on the growth characteristics and establishment rates of the $Z$. matrella genotypes 'Shadow Turf' and 'DALZ 0501'. In this research, establishment rates of 'Shadow Turf' and 'DALZ 0501' were observed to be similar to that of 'Zorro'.

Differences in the growth habit and dry matter partitioning of zoysiagrass may impact establishment rate. Leaf area ratio (LAR) and specific leaf area (SLA) are often used to examine turfgrass growth. Patton et al. (2007c) observed higher LAR and SLA values for 'Meyer' and 'Diamond' but lower crop growth rate (CGR) values. Increased LAR and SLA values for these genotypes may indicate greater leaf production but less stem production. Greater allocation to leaf production than stem production may explain the slower establishment rates.

Planting 'Shadow Turf' zoysiagrass plugs in May resulted in the highest percent cover at the end of the season in both years. However, initial establishment of plugs planted in May was slower than plugs planted in June or July. Patton et al. (2004) observed the greatest turfgrass cover ( $91 \%$ to $100 \%)$ of 'Zenith'

Table 4. Accumulative $\mathrm{GDD}^{\mathrm{z}}$ experienced by 'Shadow Turf' zoysiagrass plugs 6 and 16 WAP $^{y}$ in 2006 and 2007 at Lubbock, TX, at a base temperature of $5^{\circ} \mathrm{C}$.

\begin{tabular}{lccccc}
\hline & \multicolumn{2}{c}{ Accumulative GDD $\left(5{ }^{\circ} \mathrm{C}\right.$ base temp $)$} \\
\cline { 2 - 3 } \cline { 5 - 6 } Planting & \multicolumn{2}{c}{2006} & & \multicolumn{2}{c}{2007} \\
\cline { 2 - 5 } date & 6 WAP & 16 WAP & & 6 WAP & 16 WAP \\
\hline May & 919 & 2358 & & 726 & 2146 \\
June & 940 & 2171 & & 834 & 2213 \\
July & 848 & 1638 & & 890 & 1989 \\
\hline
\end{tabular}

${ }^{\mathrm{z}}$ GDD $=$ growing degree-days.

${ }^{\mathrm{y}} \mathrm{WAP}=$ weeks after planting. 
zoysiagrass when it was seeded 1 June 2000 and 2001. Turfgrass coverage of 'Zenith' zoysiagrass seeded on 15 July and 1 Aug. ranged from $33 \%$ to $64 \%$ and $14 \%$ to $47 \%$, respectively (Patton et al., 2004). Similar results were reported for buffalograss with decreases in percent turfgrass cover resulting from late summer planting dates (Frank, 1996). Gatian-Gaitan et al. (1998) also observed decreases in percent buffalograss [Buchloe dactyloides (Nutt.) Engelm.] cover when it was planted after 15 July.

The highest percent cover in the minimal amount of time was observed for 'Shadow Turf' zoysiagrass plugs planted at closer spacings. Plugs spaced on 15.2- $\mathrm{cm}$ centers resulted in the greatest initial and season-ending zoysiagrass cover regardless of planting date. Establishing zoysiagrass from plugs at this spacing is not always the most cost-efficient method as a result of increased inputs per unit area. Results indicate that wider plug spacings (22.9 to $38.1 \mathrm{~cm}$ ) may still produce adequate turfgrass cover (greater than $85 \%$ ) if planted at an earlier planting date. 'Shadow Turf' zoysiagrass plugs planted 38.1 to $61.0 \mathrm{~cm}$ apart did not reach adequate coverage regardless of planting date and year, except when planted on 26 May 2006. Planting plugs at these spacings may not ensure adequate zoysiagrass coverage at the end of one growing season.

Accumulation of GDD by zoysiagrass plugs planted at various dates throughout the growing season may explain observed differences in turfgrass cover between 2006 and 2007. Less GDD accumulated by plugs planted in May, followed by increasing GDD accumulation may explain differences in initial and long-term coverage (Table 4). Less zoysiagrass cover was observed in 2007 compared with 2006 regardless of planting date. Air temperatures during the spring and summer were considerably lower in 2007 than 2006. The number of accumulated GDDs in 2007 was lower than the GDDs accumulated in 2006. Initial accumulated GDDs in 2006 ranged from 848 to 9196 WAP and 1638 to 235816 WAP, whereas accumulated GDDs in 2007 ranged from 726 to $8906 \mathrm{WAP}$ and 1989 to 221316 WAP (Table 4).

Although successful zoysiagrass plug establishment was observed in this research in both years, we must consider that success may have been greater if zoysiagrass growth was examined from sprigs. Hall et al. (1998) observed quicker establishment of several zoysiagrass genotypes from sprigs than plugs. However, the partitioning of zoysiagrass genotypes based on establishment rates were similar for both vegetative propagation methods (Hall et al., 1998). Thus, the rate of establishment may have been greater for the genotypes if this experiment used sprigging instead of plugging; however, the genotypic differences would likely have been similar.

Patton et al. (2007c) examined the growth and establishment of 35 Zoysia spp. genotypes from vegetative plugs. Evaluation of more $Z$. japonica and Z. matrella genotypes in this research may have provided additional establishment rate comparisons and further classification of 'Shadow Turf' and 'DALZ 0501' growth rates.

Results from this study suggest that selecting zoysiagrass genotypes with quicker establishment rates may reduce the amount of time required for adequate $(85 \%$ or greater) turfgrass cover. Late spring or early summer planting dates may provide the greatest zoysiagrass cover when established from plugs. Planting later in the summer may still be possible, but zoysiagrass plugs require closer spacing to reach adequate turfgrass coverage by the end of the first growing season. Using early planting date and 15.2 to $30.5-\mathrm{cm}$ plug spacings may result in the quickest turfgrass cover when establishing zoysiagrass from plugs. Selecting zoysiagrass genotypes with faster short-term (6 to 12 weeks) establishment may be plausible; however, long-term (18 weeks or greater) establishment and cover were not dependent on genotype based on the methods and observations of this research.

\section{Literature Cited}

Barrios, E.P., F.J. Sundstrom, D. Babcock, and L. Leger. 1986. Quality and yield response of four warm-season lawngrasses to shade conditions. Agron. J. 78:270-273.

Beard, J.B. 1973. Turfgrass: Science and culture. 1st Ed. Prentice-Hall, Engelwood Cliffs, NJ.

Danneberger, T.K. and J.M. Vargas, Jr. 1984. Annual bluegrass seedhead emergence as predicted by degree-day accumulation. Agron. J. 76:756758.

Engelke, M.C. and S. Anderson. 2003. Zoysiagrasses (Zoysia spp.), p. 271-286. In: Casler, M.D. and R.R. Duncan (eds.). Turfgrass biology, genetics, and breeding. 1st Ed. Wiley, Hoboken, NJ.

Forbes, I. and M.H. Ferguson. 1947. Observations on the zoysia grasses. Greenskeepers' Reporter 15:7-9.

Frank, K.W. 1996. Date of planting on seeded turftype buffalograss. MS thesis, University of Nebraska-Lincoln, Lincoln, NE.

Gatian-Gaitan, F., C.B. McKenney, and D.L. Auld. 1998. Effect of burrs vs. caryopses and planting date on establishment of seeded buffalograss in the Southern Great Plains. Crop Sci. 38:795800.

Hall, M.H., R.A. White, J.E. Gaudreau, W.G. Menn, and G.R. Taylor. 1998. Zoysiagrass cultivar study. Texas Turfgrass Res. Rpt. TURF-97:33.

Harivandi, A., L. Wu, C. Elmore, and W.L. Hagan. 1995. Buffalograss establishment studies. Calif. Turfgrass Cult. 45:7-10.

Henry, J.M., S. Tjosvold, and V.A. Gibeault. 1988. Zoysiagrass establishment. Calif. Turfgrass Cult. 38:1-4.

Hume, E.P. and R.H. Freyre. 1950. Propagation trials with Manila grass, Zoysia matrella in Puerto Rico. Proc. Amer. Soc. Hort. Sci. 55: 517-518.

Madakadze, I., B.E. Coulman, K. Stewart, P. Peterson, R. Samson, and D.L. Smith. 1998. Phenology and tiller characteristics of big bluestem and switchgrass cultivars in a short growing season area. Agron. J. 90:489-495.

Marcum, K.B., S.J. Anderson, and M.C. Engelke. 1998. Salt gland ion secretion: A salinity toler- ance mechanism among five zoysiagrass species. Crop Sci. 38:806-810.

Morton, S.J., M.C. Engelke, and R.H. White. 1991. Performance of four warm-season turfgrass genera cultured in dense shade III Zoysia spp. Texas Agr. Exp. Stn. Prog. Rep. 4894:51-52.

Patton, A.J., S.M. Cunningham, J.J. Volenec, and Z.J. Reicher. 2007a. Differences in freeze tolerance of zoysiagrasses: II. Carbohydrate and proline accumulation. Crop Sci. 47:2170-2181.

Patton, A.J., S.M. Cunningham, J.J. Volenec, and Z.J. Reicher. 2007b. Differences in freeze tolerance of zoysiagrasses: I. Role of proteins. Crop Sci. 47:2162-2169.

Patton, A.J., J.J. Volenec, and Z.J. Reicher. 2007c. Stolon growth and dry matter partitioning explain differences in zoysiagrass establishment rates. Crop Sci. 47:1237-1245.

Patton, A.J., G.A. Hardebeck, D.W. Williams, and Z.J. Reicher. 2004. Establishment of bermudagrass and zoysiagrass by seed. Crop Sci. 44: 2160-2167.

Patton, A.J. and Z.J. Reicher. 2007. Zoysiagrass species and genotypes differ in their winter injury and freeze tolerance. Crop Sci. 47:16191627.

Qian, Y.L. and M.C. Engelke. 1999a. 'Diamond' zoysiagrass as affected by light intensity. J. Turfgrass Manage. 3:1-13.

Qian, Y.L. and M.C. Engelke. 1999b. Performance of five turfgrasses under linear gradient irrigation. HortScience 34:893-896.

Qian, Y.L., M.C. Engelke, and M.J.V. Foster 2000. Salinity effects on zoysiagrass cultivars and experimental lines. Crop Sci. 40:488-492.

Richardson, M.D. and J.W. Boyd. 2001. Establishing Zoysia japonica from sprigs: Effects of topdressing and nitrogen fertility. HortScience 36:377-379.

Sifers, S.I., J.B. Beard, and M.H. Hall. 1992a. Comparative characterizations of four commercially available cultivars and four experimental selections of zoysiagrass (Zoysia spp.) for 1990, College Station, Texas. Texas Agr. Expt. Sta. 4987:31-33.

Sifers, S.I., J.B. Beard, and M.H. Hall. 1992b. Comparative establishment rates and initial performance characteristics of four commercially available zoysiagrasses (Zoysia $\mathrm{spp}$.) cultivars and four experimental selections for 1988 and 1989, College Station, Texas. Texas Agr. Expt. Sta. 4896:29-31.

Turgeon, A.J. 2008. Turfgrass management. 8th Ed. Prentice Hall, Upper Saddle River, NJ.

Unruh, J.B., R.E. Gaussoin, and S.C. Wiest. 1996. Basal growth temperatures and growth rate constants of warm-season turfgrass species. Crop Sci. 36:997-999.

Valentini, N., G. Me, F. Spanna, and M. Lovisetto. 2004. Chilling and heat requirement in apricot and peach varieties. Acta Hort. 636:199-203.

Warmund, M.R., R. Fuller, and J.H. Dunn. 1998 Survival and recovery of 'Meyer' zoysiagrass rhizomes after extracellular freezing. J. Amer. Soc. Hort. Sci. 123:821-825.

White, R.H., M.C. Engelke, S.J. Anderson, B.A. Ruemmele, K.B. Marcum, and G.R. Taylor, II. 2001. Zoysiagrass water relations. Crop Sci. 41:133-138.

Zavalloni, C., J.A. Andresen, and J.A. Flore. 2006. Phenological models of flower bud stages and fruit growth of 'Montmorency' sour cherry based on growing degree-day accumulation. J. Amer. Soc. Hort. Sci. 131:601-607. 